\title{
Sox18 Is Transiently Expressed during Angiogenesis in Granulation Tissue of Skin Wounds with an Identical Expression Pattern to Flk-1 mRNA
}

\author{
Ian A. Darby, Teresa Bisucci, Smiriti Raghoenath, Jane Olsson, \\ George E. O. Muscat, and Peter Koopman
}

Microvascular Biology and Wound Healing Group (IAD, TB), Department of Human Biology, RMIT University, Bundoora; and Centre for Molecular and Cellular Biology (SR, JO, GEOM, PK), The University of Queensland, Brisbane, Australia

\begin{abstract}
SUMMARY: Sox18 encodes a member of the Sry-related high mobility group box (SOX) family of developmental transcription factors. Examination of Sox18 expression during embryogenesis has shown that Sox18 is expressed transiently in endothelial cells of developing blood vessels, and mutations in Sox18 have been found to underlie the mouse vascular and hair follicle mutant ragged. In this study we have examined the expression of Sox18 in angiogenesis during wound healing. Full-thickness skin wounds were created in mice, and subsequent expression of vascular endothelial growth factor (VEGF), the VEGF receptor Flk-1, $\alpha 1$ (iv) collagen (Col4a1), and Sox18 were studied using in situ hybridization. As has been previously reported, VEGF was expressed predominantly in the keratinocytes at the wound margins. Sox18 expression was found five days after wounding during capillary sprouting in granulation tissue and persisted through the proliferative phase of healing, but was not detected in fully epithelialized wounds 21 days after wounding. Sox18 mRNA expression was detected in capillaries within the granulation tissue and showed an identical pattern of distribution to Flk-1 and Col4a1 mRNA expression in endothelial cells. Immunostaining with a polyclonal anti-Sox18 antibody showed SOX18 protein localized in capillary endothelial cells within the granulation tissue. Capillaries in the subcutaneous tissue of unwounded skin showed no Sox18 expression. Sox18 may therefore represent a transcription factor involved in the induction of angiogenesis during wound healing and tissue repair, but not in the maintenance of endothelial cells in undamaged tissue. (Lab Invest 2001, 81:937-943).
\end{abstract}

$T$ he control of angiogenesis during tissue repair events is of crucial importance and disturbances of this process may be implicated in impaired healing such as that seen in various disease states and in aging (Swift et al, 1999). The events occurring during angiogenesis rely on expression of the appropriate growth factors, the presence of receptors for the growth factors concerned, and the subsequent induction of genes encoding factors that are involved in the cell migration, such as matrix metalloproteinase and plasminogen activator. Several growth factors involved in the induction of angiogenesis have been described. These include transforming growth factor beta (TGF- $\beta$ ) (Kuzuya and Kinsella, 1994), basic fibroblast growth factor (bFGF) (Montesano et al, 1986), and vascular endothelial cell growth factor (VEGF) (Frank et al, 1995; Nissen et al, 1998).

In this study we have examined the expression in wound healing of the novel transcription factor gene, Sox18. Sox genes encode a large family of transcription factors with important and diverse roles in embry-

Received December 22, 2000.

Address reprint requests to: Dr. Ian A. Darby, Microvascular Biology and Wound Healing Group, Department of Human Biology, RMIT University, PO Box 71, Bundoora, Victoria 3083, Australia. E-mail: ian.darby@rmit.edu.au onic development (Wegner, 1999). For example, the sex-determining gene Sry is critical for the differentiation of Sertoli cells during mammalian testis development (Koopman et al, 1991; Sinclair et al, 1990), Sox9 is required for chondrocyte differentiation (Bi et al, 1999; Wright et al, 1995) and is defective in the skeletal dysmorphology syndrome campomelic dysplasia (Foster et al, 1994; Wagner et al, 1994), and Sox10 is required for neural crest development and is defective in the neural crest disorder WaardenburgHirschsprung disease and the corresponding mouse model dominant megacolon (Pingault et al, 1998; Southard-Smith et al, 1998). The high mobility group (HMG) box characteristic of SOX proteins is a 79 amino acid domain that confers DNA sequencespecific binding to double-stranded DNA, and several SOX proteins have been shown to act as transcriptional activators or repressors.

We have previously described the isolation, sequence, expression, mapping, and biochemical characterization of the Sox18 gene and corresponding protein. Sox18 binds sequence-specifically to DNA and is able to function as a classic trans-activating transcription factor (Hosking et al, 1995). Sox18 is expressed in developing blood vessels in mouse embryos (Pennisi et al, 2000) and in adult lung, heart, and skeletal muscle tissues (Dunn et al, 1995). Expression 
is first detected in the allantois and yolk sac blood islands at $7.5 \mathrm{dpc}$ and persists at these sites until 8.5 days post coitum (dpc) (Pennisi et al, 2000). Subsequently, Sox18 is expressed in the paired dorsal aortae and the heart. In addition to expression in vessels formed by vasculogenesis, such as the dorsal aortae, Sox18 expression is associated with those formed by angiogenesis, such as the intersomitic vessels and capillary network. Sox18 expression in the mouse embryo is indistinguishable from that of the endothelial marker Flk-1 (Pennisi et al, 2000). These observations indicate that Sox18 is associated with vascular endothelial development from the earliest stages. Sox18 expression is transient in the mouse embryo, consistent with the possibility that Sox18 protein might act as part of a molecular switch mechanism for endothelial cell differentiation. We recently found that mutations in Sox18 underlie the vascular and hair follicle mouse mutant ragged, providing clear evidence for a role for Sox18 in blood vessel development and/or function (Pennisi et al, 2000).

Because Sox18 is induced during blood vessel growth in embryogenesis, we hypothesized that it is likely to be involved in angiogenesis occurring in adult life. In this study we report that Sox18 is expressed during angiogenesis in wound healing in adult mice and rats but is undetectable in unwounded skin. Sox18 expression is confined in the granulation tissue to endothelial cells of sprouting vessels, as shown by an identical pattern of expression to that shown by Flk-1 and $\alpha 1$ (iv) collagen (col4a1).

\section{Results}

\section{VEGF}

VEGF expression was detected in keratinocytes of the epidermis in all samples studied. There was a marked increase in the level of VEGF mRNA expression in the proliferative keratinocytes at the wound margins (Fig. 1a). VEGF expression in keratinocytes of the epidermis has been previously reported, as has VEGF expression in macrophages. In this study we also observed strong labeling for VEGF mRNA in cells present in the skeletal muscle layer underlying the wound tissue (Fig. 1b). This has not been previously reported
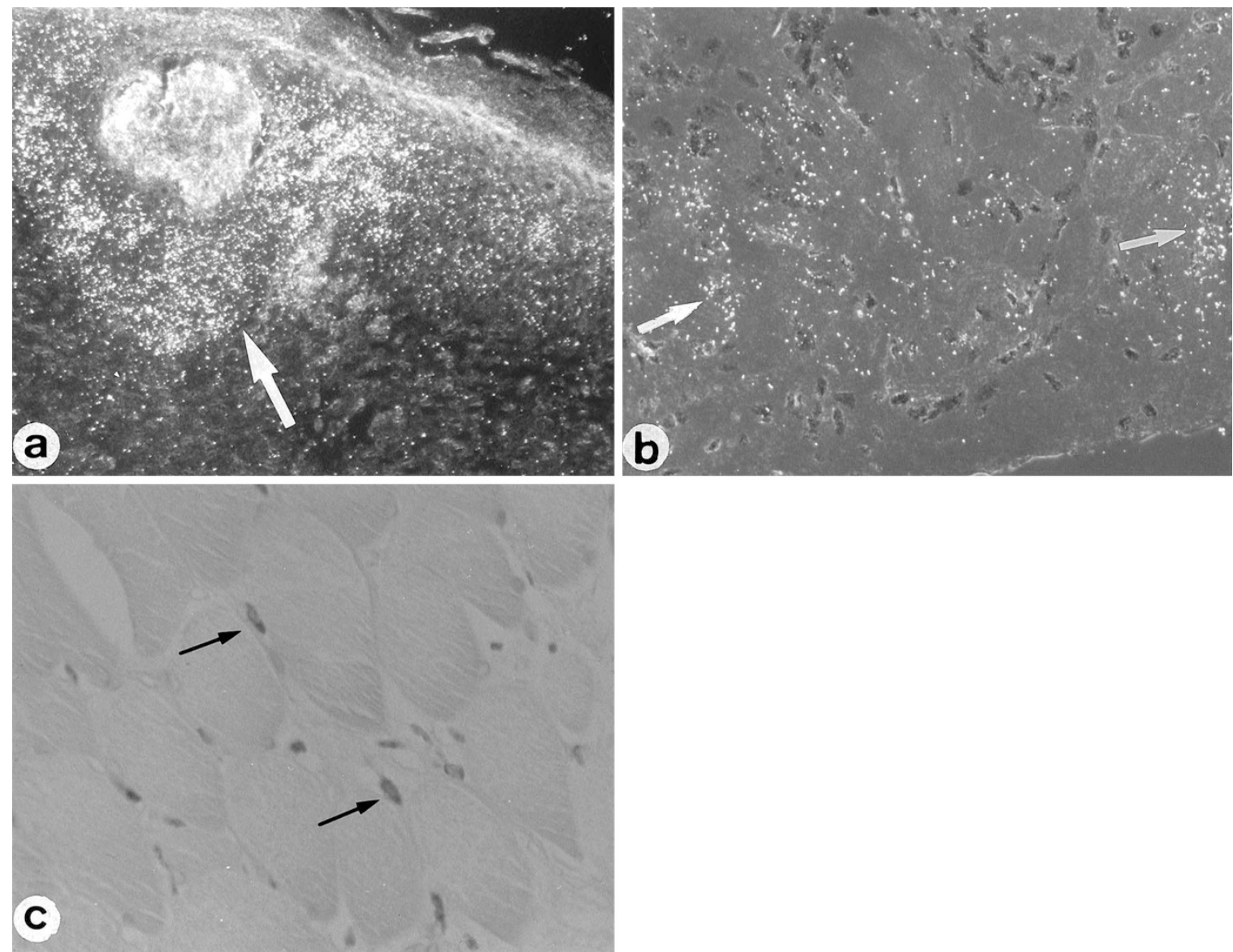

Figure 1.

Vascular endothelial growth factor (VEGF) expression during wound healing. a, VEGF mRNA expression in a skin wound (five days after wounding) showing a high level of VEGF mRNA expression in keratinocytes at the wound margin, corresponding to hyperproliferative keratinocytes (arrow). Dark-field micrograph, original magnification, $\times 200$. b, VEGF mRNA expression was also detected in the skeletal muscle beneath the granulation tissue between muscle fibers (arrows). Dark field microscopy, original magnification, $\times 200$. c, Immunostaining for the macrophage/monocyte marker ED-1 in rat wound tissue showed a similar distribution of cells to VEGF mRNA labeling, suggesting cells in the skeletal muscle layer expressing VEGF mRNA may be of the macrophage/monocyte lineage (original magnification, $\times 200)$. 
and may represent induction of VEGF expression in cells present between muscle fibers. Wound tissue from rats showed the same distribution of VEGFexpressing cells. High-power magnification suggests that the VEGF-positive cells in the skeletal muscle tissue were not capillary endothelial cells. These cells show a similar distribution to cells labeled with the rat macrophage/monocyte marker ED-1 (Fig. 1c). Sections probed with a sense probe for VEGF showed no labeling above background.

\section{Sox18}

Sox18 expression was found in capillary endothelial cells throughout the granulation tissue but not in capillaries in unwounded surrounding tissue. Sox18 expression was detectable in capillary endothelial cells of sprouting vessels in the granulation tissue (Fig. 2a). Both early wound biopsies taken five days after wounding (Fig. 2b), and wound biopsies taken 16 days after wounding, when reepithelialization was complete (Fig. 2c), showed high levels of Sox18 mRNA expression. Sox18 mRNA expression was identical in pattern to that of Flk-1 expression and col41a mRNA expression, strongly suggesting it was confined to capillary endothelial cells in the granulation tissue. In all of the wound sections examined, unwounded skin distant from the wound site was included in the biopsy. Sox18 expression was not observed in capillaries in the subcutaneous tissue distant from the wound site (Fig. $2 d)$. Similar to the localization of VEGF mRNA, some Sox18 mRNA expression was detectable in vessels at the periphery of the skeletal muscle beneath the granulation tissue (Fig. 3a) and occasionally in larger vessels at the base of the granulation tissue, such as the arteriole illustrated in Figure $3 \mathrm{~b}$. In wounds that were fully reepithelialized after 21 days, Sox 18 mRNA expression was undetectable (Fig. 3c). Immunostaining with an affinity-purified anti-Sox18 polyclonal an-
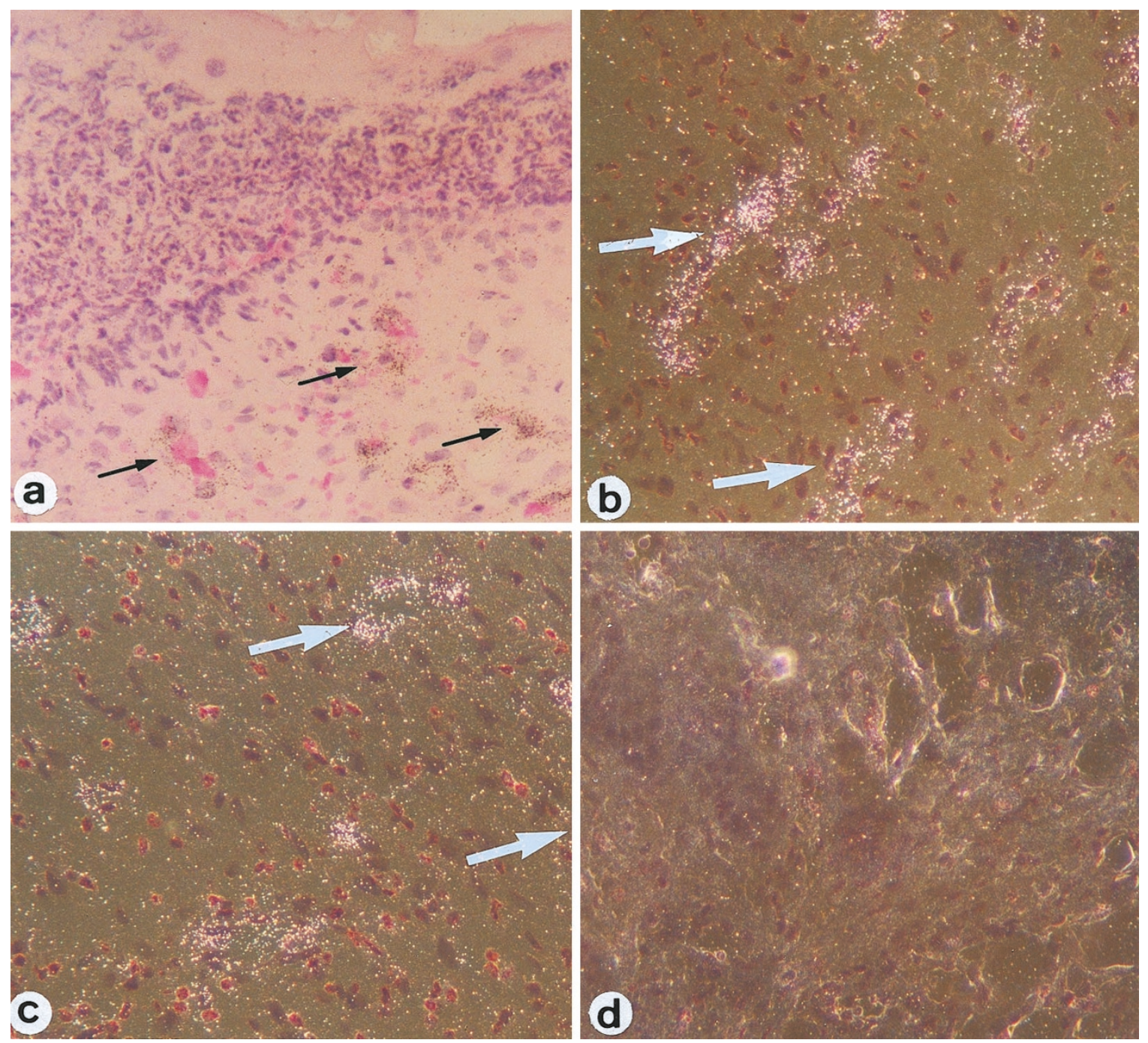

Figure 2.

a, Sox18 mRNA expression was detected in endothelial cells in granulation tissue after wounding (arrows). b, Sox18 expression was detectable early after wounding (five days after wounding) in many capillaries in the granulation tissue (arrows). Dark-field micrograph, original magnification, $\times 200$. c, Sox18 mRNA expression was still detected after the wound had reepithelialized at 16 days after wounding (arrows). Dark-field micrograph, original magnification, $\times 200$. d, Capillaries in dermal tissue distant from the wound site showed no expression of Sox18 mRNA. Dark-field micrograph, original magnification, $\times 200$. 

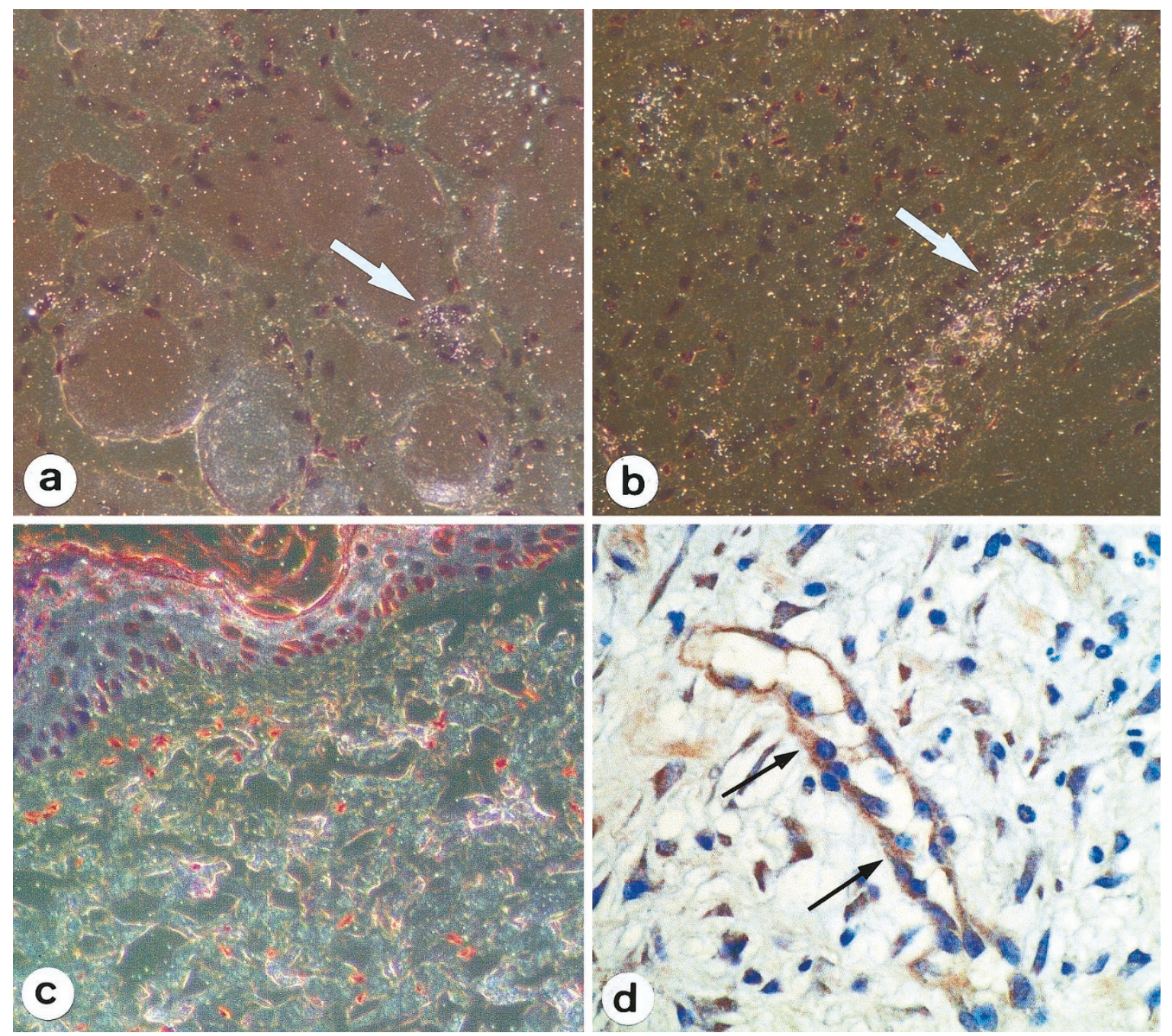

Figure 3.

a, Sox18 mRNA was detected in vessels (arrow) within the skeletal muscle layer adjacent to the base of the wound (7 days after wounding). b, In some biopsies, Sox18 mRNA expression was seen in some larger vessels at the base of the granulation tissue, such as the arteriole shown here (arrow). Dark-field micrographs, original magnification, $\times 200$. c, In wounds that were fully reepithelialized after 21 days, Sox18 mRNA expression was undetectable. d, Immunostaining with anti-SOX18 polyclonal antibody shows SOX18 protein present in a capillary (arrow) within granulation tissue biopsied 10 days after wounding.

tibody showed cytoplasmic staining predominantly in capillaries of the granulation tissue (Fig. 3d). Other cell types, such as keratinocytes adjacent to the wound, were unstained and endothelial cells of vessels in adjacent dermis were unstained (results not shown).

\section{Flk-1}

Flk-1 mRNA expression was detected in endothelial cells of vessels in the granulation tissue at all time points studied; that is, both early in wound healing (five days) when capillaries are sprouting (Fig. 4a) and late in wound healing when reepithelialization is complete (16 days) (Fig. 4b). Capillaries in the dermis adjacent to the wound remained negative for Flk-1 expression (not shown). Dark-field microscopy of sections from these two time points, five days after wounding (Fig. 4c) and 16 days after wounding (Fig. $4 d)$, shows an identical pattern of Flk-1 mRNA expression to that seen with Sox18. Flk-1 expression colo- calized with col41a mRNA expression, a marker of endothelial cells in the granulation tissue as sprouting capillaries synthesize new basement membrane (not shown).

\section{Discussion}

Angiogenesis is an important component of the tissue repair process in the skin and other organs. Many of the growth factors that are involved in angiogenesis have been identified, as have their receptors. These include TGF- $\beta$ (Kuzuya and Kinsella, 1994), bFGF (Montesano et al, 1986), hepatocyte growth factor (HGF) (Hayashi et al, 1999), connective tissue growth factor (CTGF) (Shimo et al, 1999), and VEGF (Frank et al, 1995; Nissen et al, 1998). To be induced, angiogenesis also requires the expression of other genes, examples being the genes involved in cell migration through the extracellular matrix, such as matrix metalloproteinases, tissue inhibitor of metalloproteinase, 

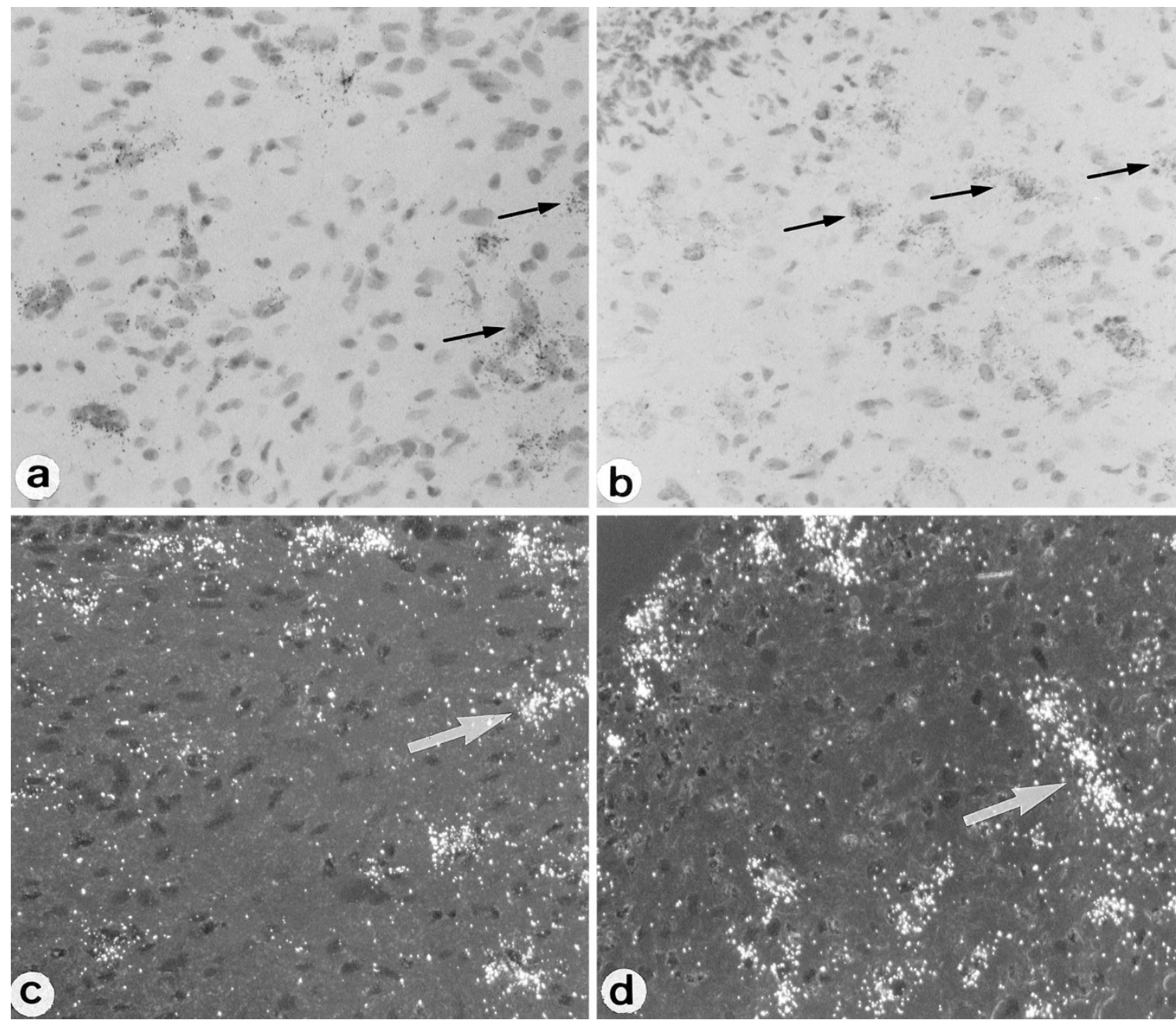

Figure 4.

Flk-1 expression during wound healing. Flk-1 mRNA expression was confined to endothelial cells (arrows) within the granulation tissue and was expressed throughout healing, shown here in granulation tissue 5 days (a) after wounding and 16 days (b) after wounding. Bright-field micrograph, original magnification, $\times 200$. Dark-field micrographs of granulation tissue, 5 days (c) and 16 days (d) after wounding when reepithelialization has occurred, show Flk-1 mRNA expression is detectable in granulation tissue capillaries with an identical pattern to Sox18 mRNA expression (original magnification, $\times 200$ ).

and plasminogen activator and its inhibitor (Pepper et al, 1998). The mechanisms by which these genes are induced and the transcription factors that regulate them remain largely unknown.

In this study we have identified expression of a novel transcription factor gene, Sox18, during angiogenesis in a mouse model of wound healing, and we have studied Sox18 expression compared with that of genes encoding VEGF, Flk-1, and col4a1. VEGF expression is predominantly localized in keratinocytes at the wound margins, whereas the receptor for VEGF, Flk-1, is localized on capillary endothelial cells within the granulation tissue. VEGF expression was also observed close to skeletal muscle cells in the layer of skeletal muscle passing through the subcutaneous tissue. This has not previously been reported and may represent VEGF expression in monocyte/macrophage cells present in this tissue, possibly induced by the tissue injury and resultant hypoxia. Immunostaining with a monocyte/macrophage marker of rat wound sections showed a high number of ED-1-positive cells in this location, with a similar distribution to the VEGF-positive cells. Interestingly, there was some evidence of Sox18 and Flk-1 in this region, suggesting that vessel sprouting may occur from this site, driven by locally produced VEGF.

Sox18 expression was localized on capillary endothelial cells in the granulation tissue but not in capillaries of the dermis surrounding the wound site. In situ hybridization detected Sox18 mRNA expression in an identical pattern to that seen for Flk-1 and col4a1 mRNA expression, confirming that it was expressed by endothelial cells. These data suggest that Sox18 is induced only in endothelial cells that are involved in angiogenesis, that is, endothelial cells that are undergoing proliferation and migration as capillary elongation occurs. Sox18 expression was maintained in capillaries of the granulation tissue throughout healing, being detected at early time points, five days after wounding, when migration and elongation of capillaries is occurring through a provisional matrix, and was still detectable at 16 days after wounding, when the 
wound is reepithelialized and granulation tissue remodeling has commenced. The absence of detectable Sox18 expression in endothelial cells of the surrounding unwounded tissue suggests that Sox18 expression is not required for maintenance of endothelial cells once capillaries are formed. This finding is consistent with the transient nature of Sox18 expression during blood vessel development in embryos (Pennisi et al, 2000).

In conclusion, Sox18 appears to be a marker of angiogenesis, and may be involved in activation of genes involved in this process during wound repair. The signal for induction of Sox18 expression and the specific genes that are activated by SOX18 protein remain to be elucidated. Because delayed angiogenesis may inhibit normal wound repair (Swift et al, 1999), understanding the transcription factors that are involved in normal angiogenesis may provide future targets for therapy in impaired healing.

\section{Materials and Methods}

\section{Generation of Wound Tissue}

A full-thickness skin wound model was used in this study (Darby et al, 1997). Mice (8-week-old C57/BI6) were anesthetized using ketamine and xylazine, the skin on the mid-dorsal region of the animal was shaved and a 1-cm square of skin was excised using a sterile scalpel. The full-thickness wound passed through the subcutaneous tissues, including the thin layer of skeletal muscle, panniculus carnosus. The wound was irrigated with sterile saline and allowed to heal without addition of wound dressings. Wound tissue was taken at various time points after wounding, from animals killed by anesthetic overdose and cervical dislocation. A similar wound model was used to obtain granulation tissue samples from adult (8week-old) Sprague Dawley rats, with $1 \mathrm{~cm} \times 1 \mathrm{~cm}$ full-thickness wounds being created on rats and tissue taken at the same time points as for the mice experiments. All tissue samples were fixed in $4 \%$ paraformaldehyde and processed routinely for paraffin embedding. All animal experiments were approved by the animal experimentation ethics committee of RMIT University.

\section{In Situ Hybridization}

Labeled cRNA probes for Sox18, Flk-1, VEGF, and Col4a1 were generated from cDNA inserts cloned into various transcription vectors, using the appropriate RNA polymerase enzyme and ${ }^{33} \mathrm{P}-$ UTP (NEN). Probes were provided by Dr. Stephen Stacker, Ludwig Institute, Melbourne, Australia (VEGF), and Drs. Janet Rossant and Andras Nagy at the Samuel Lunenfeld Research Institute, Toronto, Canada (Flk-1), and col4a1 cDNA was purchased from American Type Culture Collection (ATCC, Manassas, Virginia). cDNA inserts of the following sizes and origins were used to produce riboprobes specific for the genes of interest. Mouse Sox18 750 bp, mouse Flk-1 800 bp, mouse VEGF $550 \mathrm{bp}$, and human col4a1 $1700 \mathrm{bp}$. Sections of wound tissue were dewaxed and treated with pronase $\mathrm{E}(125 \mu \mathrm{g} / \mathrm{ml})$, microwaved in citrate buffer, and dehydrated.

All sense and antisense probes were prepared by incorporation of ${ }^{33} \mathrm{P}$-UTP by using DNA inserts and the appropriate RNA polymerase. All probes were hydrolyzed by exposure to alkaline $\mathrm{pH}$ to produce probe lengths of approximately $150 \mathrm{bp}$. Labeled probes were counted on a scintillation counter and diluted in hybridization buffer to a concentration of 40 $\times 10^{6} \mathrm{cpm} / \mathrm{ml}$. Hybridization was carried out overnight in hybridization buffer containing $50 \%$ formamide at $55^{\circ} \mathrm{C}$. Post-hybridization washes were performed in $50 \%$ formamide at $50^{\circ} \mathrm{C}$ and unbound probe was removed by incubation of sections in RNase A (Sigma, St. Louis, Missouri) at a concentration of $150 \mu \mathrm{g} / \mathrm{ml}$ at $37^{\circ} \mathrm{C}$ for 1 hour. Positive signals were detected using Ilford K5 liquid emulsion (Cheshire, United Kingdom), and developed in Kodak D19 developer (Rochester, New York), and Ilford Hypam rapid fixer.

\section{Immunohistochemistry}

Immunohistochemistry was performed on dewaxed paraffin sections of wound tissue that had been fixed in mercuric formalin fixative (saturated mercuric chloride in $10 \%$ formalin). Mercury pigment was removed by treating sections with Lugol's iodine. Sections were then decolored by treatment in 5\% sodium thiosulfate. Immunostaining was performed for the rat macrophage marker ED-1 using a monoclonal antibody (Serotec, Kidlington, United Kingdom). Immunostaining for Sox18 protein was performed using a polyclonal antibody to mouse SOX18 protein. Specific staining was detected using appropriate secondary antibodies conjugated with biotin and avidin-biotinperoxidase complex (Vector Laboratories, Burlingame, California). Diaminobenzidine-4HCl (Sigma) was used as substrate for the color reaction. Negative controls were performed by substituting nonimmune serum for primary antibody.

\section{References}

Bi W, Deng JM, Zhang Z, Behringer RR, and de Crombrugghe $B$ (1999). Sox9 is required for cartilage formation. Nat Genet 22:85-89.

Darby IA, Bisucci T, Hewitson TD, and MacLellan DG (1997). Apoptosis is increased in a model of diabetes-impaired wound healing in genetically diabetic mice. Int $\mathrm{J}$ Biochem Cell Biol 29:191-200.

Dunn TL, Mynett-Johnson L, Wright EM, Hosking BM, Koopman PA, and Muscat GE (1995). Sequence and expression of Sox-18 encoding a new HMG-box transcription factor. Gene 161:223-225.

Foster JW, Dominguez-Steglich MA, Guioli S, Kwok C, Weller PA, Weissenbach J, Mansour S, Young ID, Goodfellow PN, Brook JD, and Schafer AJ (1994). Campomelic dysplasia and autosomal sex reversal caused by mutations in an Sryrelated gene. Nature 372:525-530. 
Frank S, Hubner G, Breier G, Longaker MT, Greenhalgh DG, and Werner S (1995). Regulation of vascular endothelial growth factor expression in cultured keratinocytes: Implications for normal and impaired wound healing. J Biol Chem 270:12607-12613.

Hayashi S, Morishita R, Nakamura S, Yamamoto K, Moriuchi $A$, Nagano $T$, Taiji $M$, Noguchi $H$, Matsumoto $K$, Nakamura T, Higaki J, and Ogihara T (1999). Potential role of hepatocyte growth factor, a novel angiogenic growth factor, in peripheral arterial disease: Downregulation of HGF in response to hypoxia in vascular cells. Circulation 100(Suppl 19):॥301-308.

Hosking BM, Muscat GEO, Koopman PA, Dowhan DH, and Dunn TL (1995). Trans-activation and DNA-binding properties of the transcription factor, Sox-18. Nucleic Acids Res 23:2626-2628.

Koopman P, Gubbay J, Vivian N, Goodfellow P, and LovellBadge R (1991). Male development of chromosomally female mice transgenic for Sry. Nature 351:117-121.

Kuzuya M and Kinsella JL (1994). Reorganization of endothelial cord-like structures on basement membrane complex (Matrigel): Involvement of transforming growth factor beta 1 . J Cell Physiol 161:267-276.

Montesano R, Vassali JD, Baird A, Guillemin R, and Orci L (1986). Basic fibroblast growth factor induces angiogenesis in vitro. Proc Natl Acad Sci USA 83:7297-7301.

Nissen NN, Polverini PJ, Koch AE, Volin MV, Gamelli RL, and DiPietro LA (1998). Vascular endothelial growth factor mediates angiogenic activity during the proliferative phase of wound healing. Am J Pathol 152:1445-1452.

Pennisi D, Gardner J, Chambers D, Hosking B, Peters J, Muscat G, Abbott C, and Koopman P (2000). Sox18 mutations underlie cardiovascular and hair follicle defects in ragged mice. Nat Genet 24:434-437.

Pepper MS, Mandriota SJ, Jeltsch M, Kumar V, and Alitalo K (1998). Vascular endothelial growth factor (VEGF)-C synergizes with basic fibroblast growth factor and VEGF in the induction of angiogenesis in vitro alters endothelial cell extracellular proteolytic activity. J Cell Physiol 177:439-452.

Pingault V, Bondurand N, Kuhlbrodt K, Goerich DE, Prıhu M-O, Puliti A, Herbarth B, Hermans-Borgmeyer I, Legius E, Matthijs G, Amiel J, Lyonnet S, Ceccherini I, Romeo G, Clayton Smith J, Read AP, Wegner M, and Goossens M (1998). Sox10 mutations in patients with WaardenburgHirschsprung disease. Nat Genet 18:171-173.

Shimo T, Nakanishi T, Nishida T, Asano M, Kanyama M, Kuboki T, Tamatani T, Tezuka K, Takemura M, Matsumura T, and Takigawa M (1999). Connective tissue growth factor induces the proliferation, migration, and tube formation of vascular endothelial cells in vitro, and angiogenesis in vivo. J Biochem (Tokyo) 126:137-145.

Sinclair AH, Berta P, Palmer MS, Hawkins JR, Griffiths BL, Smith MJ, Foster JW, Frischauf A-M, Lovell-Badge R, and Goodfellow PN (1990). A gene from the human sexdetermining region encodes a protein with homology to a conserved DNA-binding motif. Nature 346:240-244.

Southard-Smith EM, Kos L, and Pavan WJ (1998). Sox10 mutation disrupts neural crest development in Dom Hirschsprung mouse model. Nat Genet 18:60-64.

Swift ME, Leinman HK, and DiPietro LA (1999). Impaired wound healing and delayed angiogenesis in aged mice. Lab Invest 79:1479-1487.

Wagner T, Wirth J, Meyer J, Zabel B, Held M, Zimmer J, Pasantes J, Bricarelli FD, Keutel J, Hustert E, Wolf U, Tommerup N, Schempp W, and Scherer G (1994). Autosomal sex reversal and campomelic dysplasia are caused by mutations in and around the Sry-related gene Sox9. Cell 79: 1111-1120.

Wegner M (1999). From head to toes: The multiple facets of Sox proteins. Nucleic Acids Res 27:1409-1420.

Wright E, Hargrave MR, Christiansen J, Cooper L, Kun J, Evans T, Gangadharan U, Greenfield A, and Koopman P (1995). The Sry-related gene Sox-9 is expressed during chondrogenesis in mouse embryos. Nat Genet 9:15-20. 


\section{Erratum}

Our May 2001 issue contained a Brief Method entitled "Immunohistochemical Detection of Skin-Homing T Cells Expressing Fucosyltransferase VII (Fuc-TVII) In Vitro and In Situ” (vol 81:771-773). This article contained errors in the listings of the authors and their affiliations. The correct listings of authors and affiliations are as follows:

Yoshiko Mizukawa, Kenya Shitara, Yoshimi Yamazaki, Akihiko Kudo, Hisashi Narimatsu, and Tetsuo Shiohara

Departments of Dermatology (YM, YY, TS) and Anatomy (AK), Kyorin University School of Medicine, Mitaka, Tokyo; Tokyo Research Laboratories (KS), Kyowa Hakko Kogyo Company, Ltd., Machida, Tokyo; and Division of Cell Biology (HN), Institute of Life Science, Soka University, Hachioji, Tokyo, Japan 